\title{
Evaluation of Shelf Life of Arabica Mixed Coffee Drinks Using Accelerated Shelf Life Testing Method
}

\author{
Laras Cempaka ${ }^{1 *}$, Ajeng Qonita Nugrafitri Akbar ${ }^{1)}$, and Nurul Asiah ${ }^{1)}$ \\ ${ }^{1)}$ Department of Food Science and Technology, Bakrie University, \\ Jl. H.R. Rasuna Said, Kav. C-22, Kuningan, Jakarta, Indonesia \\ ${ }^{*}$ Corresponding author: larascempaka1988@gmail.com \\ Received: 14 June 2019 / Accepted: 3 September 2019
}

\begin{abstract}
Coffee is a popular drink that is often consumed by Indonesian people. Currently, many manufacturers develop a variety of diverse coffee beverage products to provide flavor as well as good functional properties. Arabica coffee drinks in this study were made from three parts of coffee, i.e. cascara, which is the skin of coffee fruit; green coffee beans; and roasted coffee beans. This beverage products were then packaged and stored in a ready to drink glass bottle. This study aimed to determine the shelf life of mixed Arabica coffee beverage products, using the ASLT method. Samples were stored under different temperature conditions: $4^{\circ} \mathrm{C}, 27^{\circ} \mathrm{C}$ and $37^{\circ} \mathrm{C}$. The test consisted of measuring $\mathrm{pH}$, total dissolved solids (ppm), total sugar $\left({ }^{\circ}\right.$ Brix $)$, total color difference $(\triangle \mathrm{E})$ and total plate count $(\log \mathrm{CFU} / \mathrm{mL})$. The results showed that during storage of mixed Arabica coffee drinks, a $\mathrm{pH}$ value decreased from 5.56 to 5.42-3.67, indicating that the product was getting more acidic. The number of microbes increased, from $1.92 \log$ CFU/mL to 4.64-6.37 log CFU/ $\mathrm{mL}$. Each parameter had a different activation energy value. The higher the storage temperature was proven to the smaller the activation energy. On the measurement of total microbes, the activation energy of each treatment temperature of $4^{\circ} \mathrm{C}$, $27^{\circ} \mathrm{C}$ and $37^{\circ} \mathrm{C}$ were $0.1731,0.1476$ and 0.1382 , respectively. This Arabica coffee drinks had a shelf life of 4 days if stored at $4^{\circ} \mathrm{C}$.
\end{abstract}

Keywords: Accelerated shelf life testing (ASLT), Arabica coffee bean, cascara, green bean, shelf life

\section{INTRODUCTION}

Indonesia is the fourth coffee producing country after Brazil, Vietnam, and Colombia (Kemenperin, 2017). According to data from the BPS (2018), coffee production in Indonesia is increasing every year. Coffee production in 2015 was around 602.37 thousand tons, in 2016 it reached 632 thousand tons and in 2017 it reached 636.7 thousand tons. The increasing amount of coffee production in
Indonesia each year, it makes more coffee processed products by the coffee industry (Kurniawan \& Rosyid, 2017).

According to Abduh (2018), the types of coffee that are famous in Indonesia are Robusta (Coffea canephora) and Arabica (Coffea arabica). However, Arabica coffee is often used as a raw material in the manufacture of coffee drinks because it has a superior taste and complex aroma compared 
to Robusta coffee (Rakesh et al., 2010). Coffee can be enjoyed by brewing with hot water (hot brew) and cold water (cold brew). According to the Kemenperin (2017), cold brew has become the latest trend of consuming coffee drinks that are previously served always in a hot state. Cold brew coffee is starting to become a trend with several advantages such as having less acid content and having higher caffeine levels (Fuller \& Rao, 2017).

In general, coffee commonly consumed as a drink is roasted coffee beans (Kipkorir et al., 2015). However, it is known that green coffee beans and cascara can also be used as raw material for drinks. The samples of coffee cherry pulp obtained from coffee producers from different parts of the world, differing in variety and type of processing showed significantly different contents of phenolic compounds and caffeine. Among the assessed samples, Bourbon variety originating from Congo had highest total polyphenol content and antioxidant capacity and high caffeine content. Compared to coffee and silverskin tea, cascara has high levels of caffeine and antioxidant activity (Heeger et al., 2016). Until now there have been many studies conducted on mixed Arabica and Robusta coffee products, but there has been no research on mixed coffee products: cascara, green coffee and roasted coffee. This is the development of coffee beverage products, which also can increase the added value of cascara, green coffee and roasted coffee. Coffee pulp is a natural antioxidant and tannin provider, proven to bring beneficial health aspects to a person. According to the panelist reviewed, washed process cascara was preferred to natural process cascara. Washed process cascara was always 1 or 2 points above in all attributes evaluated (color, sweetness, taste and general acceptance) (Umanzor, 2016).
Research related to shelf life is very important, especially for perishable food products. An estimated shelf life method is the ASLT method. This method is to determine the shelf life with the accelerated method by storing the product in environmental conditions that can accelerate the reaction of product quality degradation. In this method the storage conditions are set outside normal conditions so that the product can be damaged more quickly and the shelf life of the product can be determined (Arif, 2016). Based on the study of Sudibyo et al. (2010), the critical parameter that determines the shelf life of instant coffee products is the water content. The critical point value of water content is $17.98 \%$, the shelf life of the instant coffee product formulation that was studied at $30^{\circ} \mathrm{C}, 45^{\circ} \mathrm{C}$ and $50^{\circ} \mathrm{C}$ were 664 days, 437 days and 384 days, respectively.

The shelf life of food products is also very important information for consumers due to it is related to food product safety and provides quality assurance when the product reaches consumers. Information related to shelf life is one of the conditions that must be displayed on the packaging label to processed products to be traded. In this study, the drink formulation used between cascara; green beans; roasted beans is 1:1:1. This is based on preliminary research conducted on formulation that can be accepted by consumers. In additions, comparison intends that there is no dominating taste among the main ingredients of coffee due to each of the product has different characteristics, such as cascara which dominates the sour taste, green coffee dominates the beany taste while roasted coffee dominates the bitter taste. This study aimed to determine the shelf life of cascara extract, green coffee and roasted coffee mixed drinks with ASLT method. 


\section{MATERIALS AND METHODS}

The materials used in this study were dry cascara, green coffee beans, roasted coffee beans, Arabica type Java Karlos Gunung Arjuna Malang, East Java, obtained from Nomar Kopi Roastery, and the addition of brown sugar, maltodextrin and full cream milk. Roasted coffee beans are ground using a grinder. Then the cold extraction process is carried out on the roasted coffee beans and cascara for 12 hours using a french press, while the green coffee beans are extracted hot by boiling. The comparison made for extraction is $1: 15$. Then the extraction results are mixed homogeneously, which will produce a mixed drink from cascara extract, green coffee and roasted coffee added with brown sugar, maltodextrin and full cream milk to increase the flavor of the beverage product.

Accelerated Shelf Life Testing (ASLT) was carried out on samples with glass bottle packaging at $37^{\circ} \mathrm{C}, 27^{\circ} \mathrm{C}$ and $4^{\circ} \mathrm{C}$ for 12 days. The parameters tested were measurements of color $\left(\mathrm{L}^{*}, \mathrm{a}^{*}, \mathrm{~b}^{*}\right), \mathrm{pH}$, total dissolved solid (TDS), total sugar ( ${ }^{\circ}$ Brix) and total plate count (TPC). Observations were made on days $0,3,6,9,12$, and 15 .

Analysis data from observations will be entered into a graph of the relationship between storage time (days) with the average change in a quality decrease for each parameter. Then the linear regression equation $(y=b x$ $+a)$ is obtained, which is obtained by three equations for three different storage temperature conditions. Where $\mathrm{y}$ is the change in product quality, $b$ is the rate of change in the quality of the product obtained from the slope (also known as $\mathrm{k}$ ), or is called $\mathrm{k}$, $\mathrm{x}$ is the storage time (days) and a is the initial product quality value.

Then the reaction order is determined by using a zero-order graph which is the relationship between the value of $\mathrm{k}$ with the storage time and order one which is the relationship between $\ln \mathrm{k}$ with the storage time. The zero-order decrease graph is a constant quality loss and can be illustrated by the $A_{t}-A_{o}=-k t$ equation while the firstorder graph is done with a plot of $\ln \mathrm{k}$ value with long storage. The correlation of decreasing quality parameters for first-order is illustrated by the

$$
\begin{aligned}
& \ln A_{t}-\ln A_{o}=- \text { kt equation where : } \\
& A_{t}=\text { Value of the quality parameter at time } t \\
& A_{o}=\text { Initial value of quality parameter } \mathrm{A} \\
& \mathrm{k} \quad=\text { Rate of change in quality } \\
& \mathrm{t} \quad=\text { Storage time }
\end{aligned}
$$

Determination of the reaction order is based on a linear regression equation by looking at the value of $R^{2}$, where the largest $R^{2}$ value will be chosen as the reaction order. The Arrhenius approach is used by graphing the correlation of the rate of decline in product quality to the storage temperature connecting the value of $\ln$ to $1 / \mathrm{T}$. Then make the linear regression equation with the equation $\ln \mathrm{k}$ $=\ln \mathrm{k}_{0}-(\mathrm{E} / \mathrm{RT})$ approach, where $\ln \mathrm{k}_{0}=$ intercept, $\mathrm{E} / \mathrm{R}=$ slope, $\mathrm{E}=$ activation energy and $\mathrm{R}=$ ideal gas constant $=1,986 \mathrm{cal} / \mathrm{mol}{ }^{\circ} \mathrm{K}$ (Asiah et al., 2018).

After obtaining the value of $\mathrm{k}_{0}$ which is a pre-exponential factor and the value of the reaction activation energy (Ea) changes in product characteristics, the Arrhenius equation will be obtained which is the equation of reaction rate changes in the quality characteristics of drinks with the equation $\mathrm{k}=\mathrm{k}_{0}$.e$\mathrm{E} / \mathrm{RT}$ where $\mathrm{T}$ is storage temperature. Arrhenius constant values at each storage temperature can be calculated.

The parameter that has the lowest activation energy value is a key parameter. Shelf life is calculated using the reaction equation based on the reaction order. To determine the shelf life of beverage products is to enter the temperature value in the equation $\ln \mathrm{k}$ 
$=\ln \mathrm{k}_{0}-(\mathrm{E} / \mathrm{RT})$. The $\mathrm{k}$ value obtained is entered into the reaction order equation to get the shelf life of coffee drinks (Swadana \& Yuwono, 2014).

\section{RESULTS AND DISCUSSION}

\section{Quality Characteristics}

Preliminary quality characteristics need to be tested to determine the initial state of the sample before storage so that estimation of shelf life can be done through the identification of defects that occur during storage on beverage products. The quality characteristics of the initial coffee drinks can be seen in Table 1 .

Determination of the final quality $\left(\mathrm{N}_{\mathrm{t}}\right)$ of beverage products, carried out to get the value of the final quality standard of products that are carried out sensory. The test used 20 untrained panelists. This test was carried out because there were no standards for mixed coffee beverage products. The sensory test used is a triangle test. The results obtained from the percentage of rejection of $50 \%$, that the determination of the final quality of the product is determined from the physicochemical value and TPC (total plate count) at the temperature of 4 days 6 (Table 2).

\section{Quality Changes}

Determination of shelf life of mixed coffee beverage products is carried out the physicochemical testing including measurement of $\mathrm{pH}$, TDS (total dissolved solid), total sugar, total color difference, and TPC. Following are the changes in the physicochemical quality and total microbial of Arabica coffee mixed beverage products during storage.

Table 1. Initial quality characteristics of coffee beverage products

\begin{tabular}{lcr}
\hline Quality parameters & Initial quality $\left(\mathrm{N}_{0}\right)$ & Final quality $\left(\mathrm{N}_{\mathrm{t}}\right)$ \\
\hline Total sugar (TS) $\left({ }^{\circ}\right.$ Brix) & 9 & 8.97 \\
$\mathrm{pH}$ & 5.56 & 5.44 \\
Color: & & 36.22 \\
$\quad$ Brightness level (L*) & 34.29 & 4.30 \\
$\quad$ Red intensity (a*) & 4.82 & 10.59 \\
$\quad$ Yellow intensity (b*) & 11.82 & 1410 \\
Total dissolved solid (TDS) (ppm) & 1223 & 2575 \\
Total plate count (TPC) $(\mathrm{cfu} / \mathrm{mL})$ & 82.5 & \\
\hline
\end{tabular}

Table 2. Total color difference $(\triangle \mathrm{E})$ during storage

\begin{tabular}{|c|c|c|c|c|c|}
\hline \multirow{2}{*}{ Temperature $\left({ }^{\circ} \mathrm{C}\right)$} & \multirow{2}{*}{ Days to... } & \multicolumn{4}{|c|}{ Color parameters } \\
\hline & & $\Delta \mathrm{L}^{*}$ & $\Delta \mathrm{a}^{*}$ & $\Delta \mathrm{b}^{*}$ & $\Delta \mathrm{E}^{*}$ \\
\hline \multirow[t]{5}{*}{4} & 0 & 0.00 & 0.00 & 0.00 & 0.00 \\
\hline & 3 & 1.41 & -0.45 & -0.95 & 1.76 \\
\hline & 6 & 1.93 & -0.52 & -1.23 & 2.35 \\
\hline & 9 & 2.01 & -0.58 & -2.65 & 3.38 \\
\hline & 12 & 3.21 & -0.55 & -1.68 & 3.67 \\
\hline \multirow[t]{5}{*}{27} & 0 & 0.00 & 0.00 & 0.00 & 0.00 \\
\hline & 3 & -2.02 & 0.08 & -1.67 & 2.62 \\
\hline & 6 & -3.69 & -0.05 & -2.83 & 4.65 \\
\hline & 9 & -3.96 & -0.42 & -3.02 & 4.99 \\
\hline & 12 & -6.22 & -0.79 & -4.27 & 7.58 \\
\hline \multirow[t]{5}{*}{37} & 0 & 0.00 & 0.00 & 0.00 & 0.00 \\
\hline & 3 & -2.12 & -1.63 & -6.24 & 6.78 \\
\hline & 6 & -4.91 & -1.57 & -4.57 & 6.88 \\
\hline & 9 & -7.34 & -0.65 & -8.45 & 11.21 \\
\hline & 12 & -9.77 & -0.97 & -5.47 & 11.24 \\
\hline
\end{tabular}


pH

The $\mathrm{pH}$ value is the degree of acidity which shows the concentration of hydrogen ions which states the level of acid or base in a solution (Sudewa \& Hadiatna, 2017). During product storage, there is a decrease in the $\mathrm{pH}$ value (Figure 1). The lower $\mathrm{pH}$ indicates a high level of product acidity. The decrease in $\mathrm{pH}$ is due to the formation of acid in coffee beverage products produced by microbial activity, so the longer the storage is proving the more acidic the $\mathrm{pH}$ of the beverage product. This is similar to the statement of Yun et al. (2007) that the gradual decrease in $\mathrm{pH}$ is caused by chemical reactions and the growth of microorganisms. Microorganisms that grow on products can produce organic acids and breakdown hydrolytic lipids that can produce fatty acids. That is what causes a decrease in $\mathrm{pH}$.

The change in $\mathrm{pH}$ is thought to be due to the activity of microorganisms that can break down proteins, carbohydrates, fats, and other organic substances into organic acids so that it can cause a decrease in $\mathrm{pH}$ value. Microbes that can produce acids, including lactic acid bacteria or acetic acid bacteria (Rahayu \& Nurwitri, 2012).
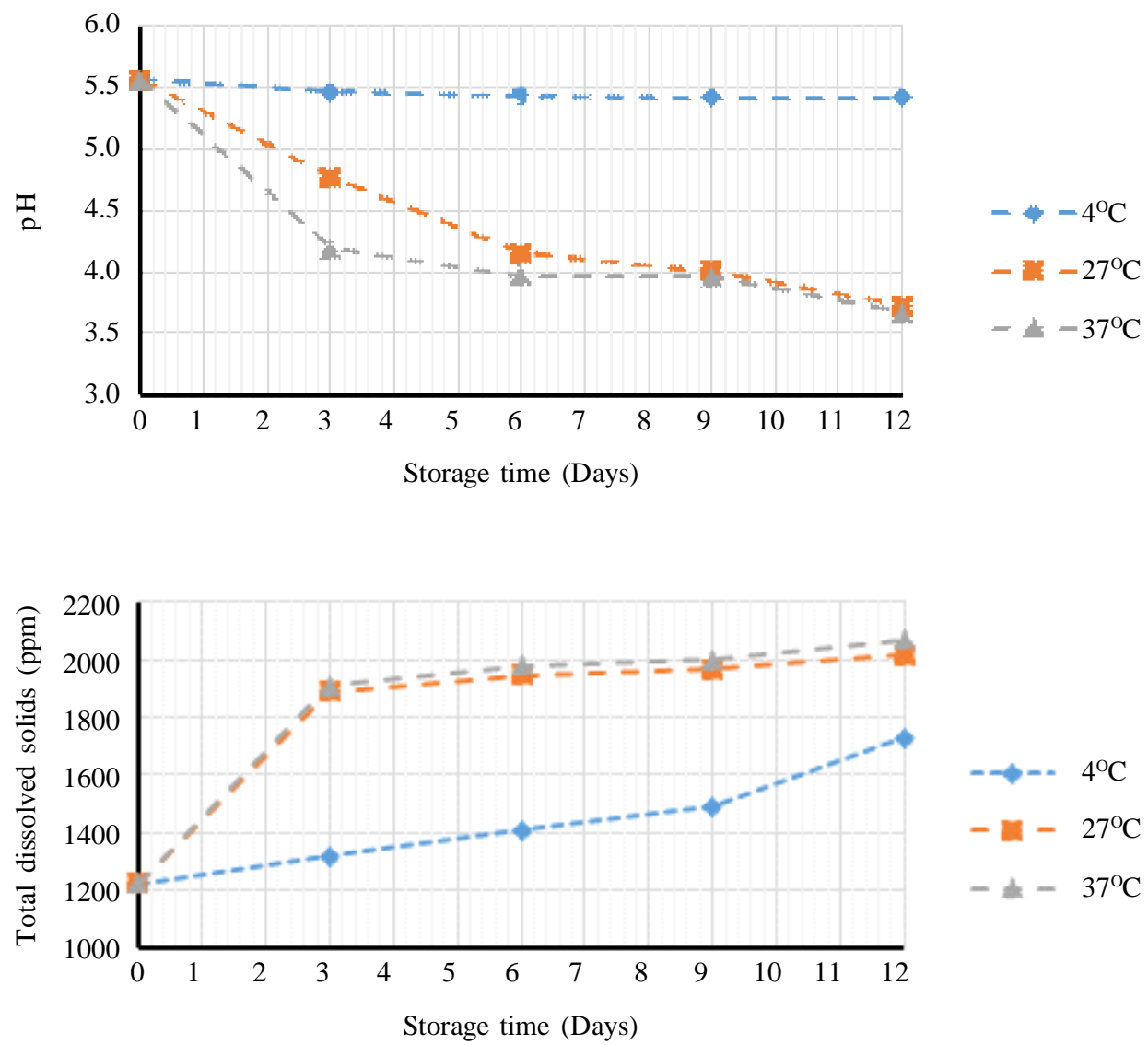

Figure 1. Changes in $\mathrm{pH}$ and TDS 
TDS

During storage of coffee beverage products, an increase in the value of TDS. This increase in TDS is due to the formation of lumps in coffee beverage products (Figure 2). Beverage products are included in the colloidal type dispersion system. A colloid is a mixture of several substances that are located between the nature of the solution and suspension. Generally, colloids have particle sizes between $1 \mathrm{~nm}$ to $100 \mathrm{~nm}$ (Adi, 2013). Colloids become unstable when coagulation occurs. This coagulation can be interpreted as one of the protein damage that occurs due to heat, resulting in clotting (Makfoeld, 2008).

During storage at $27^{\circ} \mathrm{C}$ and $37^{\circ} \mathrm{C}$, the samples formed deposits and lumps. This is due to the sample has rich nutrients. The high nutritional value of milk can cause milk to be easily damaged at high storage temperatures. The fat and protein contained therein are denatured due to heat. Rahayu \& Nurwitri (2012) explained that almost all components of milk are nutrients that are loved by microbes to grow. Microbiological damage to milk can be caused by acid production in several species of bacteria and yeast.

\section{Parameter of Total Sugar $\left({ }^{\circ} \mathrm{Brix}\right)$}

During storage of beverage products, there is a decrease in the value of total sugar. Carbohydrates (in this case sucrose) as the main substrate that can be broken down by microbes in the fermentation process into simpler sugar units, resulting in a decrease in the total value of sugar solids ( ${ }^{\circ}$ Brix). (Figure 2).

The decrease in total sugar can be caused by the conversion of polysaccharides that are soluble in reducing sugars, as well as the hydrolysis of sugars by acids where there will be the degradation of disaccharides into monosaccharides, as well as hydrolysis of sucrose. This reducing sugar is formed by microbial fermentation (Yadav et al., 2013).

\section{Total Color Difference Parameter $(\Delta \mathbf{E})$}

Color measurements are carried out using a chromameter that will produce Hunter values in the form of $\mathrm{L}^{*}, \mathrm{a}^{*}$ and $\mathrm{b}^{*}$. According to Andarwulan et al. (2011), Hunter color notation system is characterized by three color parameters are chromatic color (hue) written with the notation $\mathrm{L}^{*}, \mathrm{a}^{*}$ and $\mathrm{b}^{*}$. The notation $\mathrm{L}^{*}$ states the brightness parameter (lightness) with the value 0 means black and 100 means white. The notation $a^{*}$ represents the chromatic color mixture of red-green with positive values $\mathrm{a}^{*}$ from 0 to +100 for red and negative values a from 0 to -80 for green. Whereas the $b^{*}$ notation states the chromatic color mixture of blue-yellow with positive values of $b^{*}$ from 0 to +70 for yellow and negative $b^{*}$ from 0 to -70 for blue. As a result of a decrease in the $\mathrm{pH}$ value and an increase in the TDS value in the previous parameters, it will affect the change in the total color value during storage. The higher the storage temperature, the change in the total color value is also higher (Figure 2).

The value of $\Delta \mathrm{L}^{*}$ at $4^{\circ} \mathrm{C}$ temperature increases with a positive value during storage, which indicates that the color of the beverage product gets brighter with storage time, whereas at temperatures of $27^{\circ} \mathrm{C}$ and $37^{\circ} \mathrm{C}$ decreases the brightness during storage with a negative value, which indicates that the product is getting turbid or more colored dark. The value of $\Delta \mathrm{a}^{*}$ at $4^{\circ} \mathrm{C}, 27^{\circ} \mathrm{C}$ and $37^{\circ} \mathrm{C}$ decreases during storage with a negative value, which indicates that the coffee drink product is greenish, while the value of $\mathrm{b}^{*}$ at $4^{\circ} \mathrm{C}, 27^{\circ} \mathrm{C}$ and $37^{\circ} \mathrm{C}$ also decreases during storage with a negative value, indicating that bluishcolored coffee beverage products (Table 3 ). 

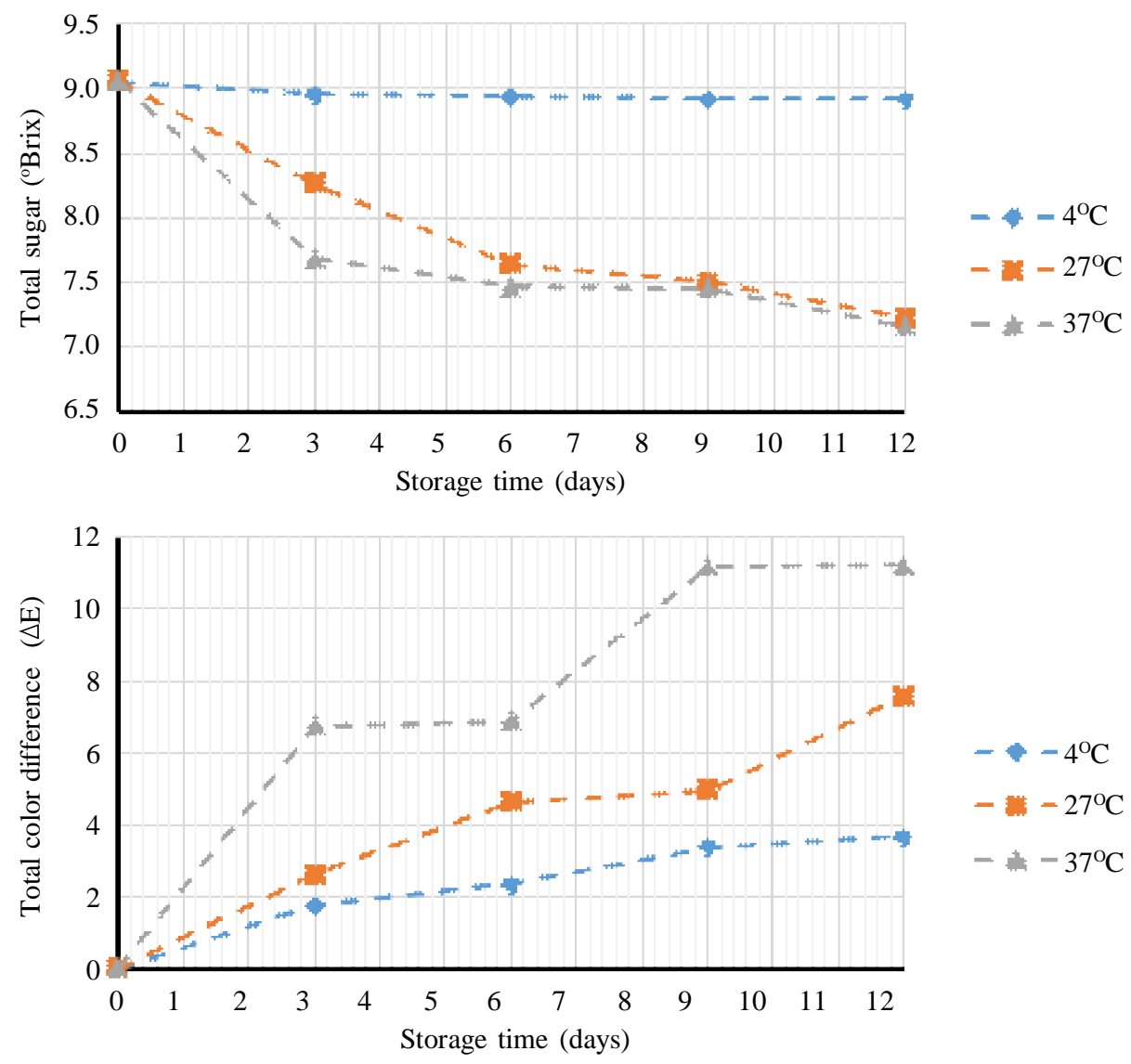

Figure 2. Change in ${ }^{\circ}$ Brix value and total color difference during storage

This color change indicates a change or decrease in product quality, according to the statement of Culver (2008), which states that color is one of the characteristics that largely determines the quality of a food product.

Research conducted by Guo et al. (2011) and $\mathrm{Xu}$ et al. (2011) grouped the value of $\Delta \mathrm{E}^{*}$ into five groups that is not visible when $\Delta E^{*} 0-0.5$, at first glance seen when $\Delta \mathrm{E}^{*} 0.5-1.0$; slightly visible when $\Delta \mathrm{E}^{*} 1.5$ - 3.0; looks good when $\Delta \mathrm{E}^{*} 3.0$ - 6.0; and clearly seen when $\Delta \mathrm{E}^{*} 6.0-12.0$.

\section{Total Plate Count}

According to Rahayu \& Nurwitri (2012), growth and activity of food-destroying microorganisms can have an impact on food quality and quantity reduction. A decrease in the $\mathrm{pH}$ parameters and total sugar ( $\left.{ }^{\circ} \mathrm{Brix}\right)$, as well as an increase in the TDS parameters during storage, indicates that there is microorganism activity in beverage products. Microorganism testing is done by testing the TPC. During storage, there is an increase in the total number of microbes in beverage products (Figure 3). The higher the storage temperature, the more microbes will be in the beverage product. Microorganism test using this TPC method can find out the total number of microorganism in the sample by growing microorganism cells that are still alive. So, that is known during storage, there is an increase in the total number of microbes in the Arabica mixed coffee beverage product. Storage at high temperature causes an increase in the number of microbes that are higher than the lower temperature. 
Table 3. Determination of the order of reaction

\begin{tabular}{|c|c|c|c|c|}
\hline \multirow{2}{*}{ Parameter } & \multirow{2}{*}{$\begin{array}{c}\text { Temperature } \\
\left({ }^{\circ} \mathrm{C}\right)\end{array}$} & \multicolumn{2}{|c|}{$\mathrm{R}^{2}$} & \multirow{2}{*}{ Order } \\
\hline & & Order 0 & Order 1 & \\
\hline \multirow{3}{*}{$\mathrm{pH}$} & 4 & 0.7529 & 0.7551 & 1 \\
\hline & 27 & 0.9145 & 0.939 & \\
\hline & 37 & 0.7254 & 0.7616 & \\
\hline \multirow{3}{*}{ TDS (ppm) } & 4 & 0.9432 & 0.9641 & 0 \\
\hline & 27 & 0.6334 & 0.6075 & \\
\hline & 37 & 0.6584 & 0.627 & \\
\hline \multirow{3}{*}{ TSS ( ${ }^{\circ}$ Brix) } & 4 & 0.9423 & 0.9421 & 1 \\
\hline & 27 & 0.5967 & 0.602 & \\
\hline & 37 & 0.8076 & 0.8264 & \\
\hline \multirow{3}{*}{ Total Color Difference $(\Delta E)$} & 4 & 0.933 & 0.9509 & 0 \\
\hline & 27 & 0.9568 & 0.9263 & \\
\hline & 37 & 0.8568 & 0.8136 & \\
\hline \multirow{3}{*}{ TPC (cfu/mL) } & 4 & 0.3655 & 0.8591 & 1 \\
\hline & 27 & 0.2443 & 0.8318 & \\
\hline & 37 & 0.338 & 0.8762 & \\
\hline
\end{tabular}

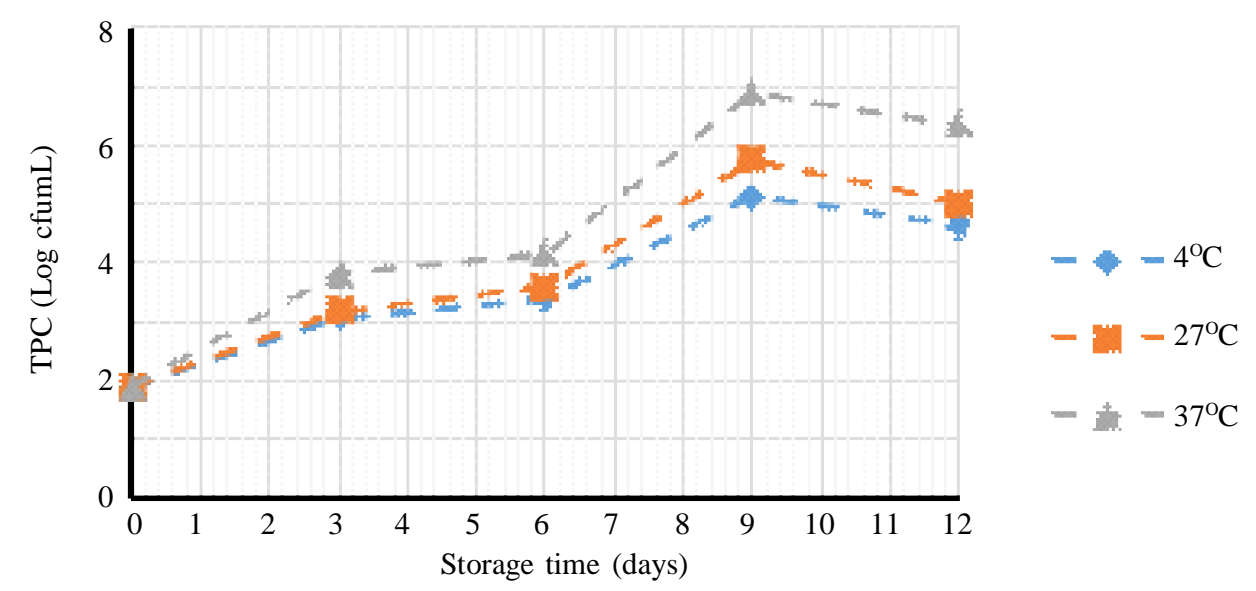

Figure 3. Changes in the total microbial value during storage

Rahayu \& Nurwitri (2012) explain that microbial growth is an increase in the number of microbes or microbial cell mass, which can be interpreted as an increase in the size of microbes. Factors that can affect the growth of microorganisms in food products are intrinsic and extrinsic factors. Intrinsic factors include acidity ( $\mathrm{pH}$ ), water activity (aw), equilibrium humidity (Eh), nutrient content, antimicrobial components, and food structure. Extrinsic factors include storage temperature and humidity content around food (Arpah, 2001). An increase in the number of microorganisms is not only influenced by a decrease in the $\mathrm{pH}$ value or total sugar ( ${ }^{\circ}$ brix), but an increase in the TPC can also be affected by the storage temperature of the product. This is similar to the statement of Rahayu \& Nurwitri (2012) that temperature is also a very important factor for microbial growth. Temperature can affect the length of the lag phase, growth speed, enzymatic activity and absorption of nutrients by microbes. The lowest temperature of microbes to grow is $-34^{\circ} \mathrm{C}$ and the highest temperature can exceed $100^{\circ} \mathrm{C}$.

\section{Shelf Life Estimation}

The Arrhenius equation can describe the correlation between changes in product quality parameters and storage temperature. This equation can be used to predict the accelera- 
tion of product damage when stored at more extreme temperatures (Asiah et al., 2018).

\section{Order of Reaction}

The choice of the kinetics of the order of the declining reaction is done by comparing the value of the correlation coefficient $\left(\mathrm{R}^{2}\right)$ in each equation, from the zero-order reaction and the first-order reaction. A reaction order with a correlation coefficient that has a greater value is the reaction order to be chosen (Table 4).

According to Syah (2012), the types of product damage classified as zero-order reactions include enzymatic degradation, nonenzymatic browning, and fat oxidation. While the types of product damage that are included in the first-order reaction are rancidity, microorganism growth, off-flavor production by microorganism, vitamin damage and protein quality loss. In zero-order reactions, the decrease in quality is constant, while in firstorder reactions occur exponentially.

After determining the reaction order, an Arrhenius approach is made to graph the correlation between the rate of decline in product quality (Ln k) and the storage temperature $(1 / \mathrm{T})$ based on the selected reaction order. Then the activation energy value will be obtained for each parameter.

\section{Critical Point}

Selection of the critical parameters of shelf life is done by determining the quality parameters that have decreased the fastest during storage that is indicated by the greatest value of the correlation coefficient $\left(\mathrm{R}^{2}\right)$, then the quality parameters most sensitive to temperature changes are seen from the lowest activation energy (Ea) value.

According to Hariyadi (2019), the activation energy is the minimum energy level needed to start a change reaction. The relationship between activation energy and reaction rate is inversely proportional. The greater the activation energy, the slower the reaction rate because the minimum energy for the reaction to occur is greater.

To determine the critical parameters seen from the smallest activation energy value of each parameter, because of the smaller the activation energy, the faster the reaction rate. The activation energy value (Ea) can be calculated by multiplying the value of $\mathrm{Ea} / \mathrm{R}$, where the $\mathrm{R}$-value is $1.986 \mathrm{cal} / \mathrm{mol}$. The parameter that has the smallest activation energy value is the total microbial parameter (Table 4).

\section{Shelf Life Calculation}

In coffee beverage products, which have the smallest activation energy value found in the total microbial parameters, with the equation $\ln \mathrm{k}=-1089(1 / \mathrm{T})+3.3491$, where the activation energy value is 2162.75 $\mathrm{cal} / \mathrm{mol}$. This reaction equation will be used to get the $\mathrm{k}$ value of each storage temperature. To obtain the shelf life of mixed arabica coffee beverage products in Table 5 .

In the Arrhenius method, the temperature is a very influential factor in decreasing the quality of food products which is suported by Hariyadi (2019). The higher the temperature, the higher the reaction rate.

Table 4. Activation energy values for each parameter of mixed coffee beverage products

\begin{tabular}{lcc}
\hline Parameter & Arrhenius equation & Activation energy $(\mathrm{cal} / \mathrm{mol})$ \\
\hline pH & $\ln \mathrm{k}=-7761.4(1 / \mathrm{T})+21.904$ & 15414.14 \\
TDS $(\mathrm{ppm})$ & $\ln \mathrm{k}=-1090.8(1 / \mathrm{T})+7.6225$ & 2166.33 \\
TSS $\left({ }^{\circ}\right.$ Brix $)$ & $\ln \mathrm{k}=-8129.7(1 / \mathrm{T})+22.243$ & 16145.58 \\
Total color difference $(\triangle \mathrm{E})$ & $\ln \mathrm{k}=-2774.5(1 / \mathrm{T})+8.7868$ & 5510.16 \\
TPC $(\mathrm{cfu} / \mathrm{mL})$ & $\ln \mathrm{k}=-1089(1 / \mathrm{T})+3.3491$ & 2162.75 \\
\hline
\end{tabular}


Cempaka et al.

Table 5. Predicted shelf life for each parameter

\begin{tabular}{|c|c|c|c|c|}
\hline Temperature $\left({ }^{\circ} \mathrm{C}\right)$ & Test parameter & $\mathrm{K}$ value & $\begin{array}{c}\text { Activation energy } \\
\text { (cal/mol) }\end{array}$ & $\begin{array}{c}\text { Shelf life prediction } \\
\text { (days) }\end{array}$ \\
\hline & Sensory & - & - & 3.88 \\
\hline 4 & $\begin{array}{l}\text { TPC } \\
\text { TDS } \\
\text { Total Color Difference } \\
\text { pH } \\
\text { TS }\end{array}$ & $\begin{array}{r}0.5586 \\
39.8289 \\
0.2924 \\
0.0022 \\
0.0008\end{array}$ & $\begin{array}{l}0.1731 \\
0.1734 \\
0.4409 \\
1.2337 \\
1.2932\end{array}$ & $\begin{array}{l}6.16 \\
4.69 \\
8.04 \\
9.88 \\
4.07\end{array}$ \\
\hline 27 & $\begin{array}{l}\text { TPC } \\
\text { TDS } \\
\text { Total Color Difference } \\
\text { pH } \\
\text { TS }\end{array}$ & $\begin{array}{r}0.7551 \\
53.8660 \\
0.6303 \\
0.0189 \\
0.0078\end{array}$ & $\begin{array}{l}0.1476 \\
0.1478 \\
0.3759 \\
1.0517 \\
1.1015\end{array}$ & $\begin{array}{l}4.56 \\
3.47 \\
3.73 \\
1.15 \\
0.43\end{array}$ \\
\hline 37 & $\begin{array}{l}\text { TPC } \\
\text { TDS } \\
\text { Total Color Difference } \\
\text { pH } \\
\text { TS }\end{array}$ & $\begin{array}{r}0.8489 \\
60.5694 \\
0.8494 \\
0.0436 \\
0.0187\end{array}$ & $\begin{array}{l}0.1382 \\
0.1384 \\
0.3521 \\
0.9849 \\
1.0316\end{array}$ & $\begin{array}{l}4.05 \\
3.08 \\
2.77 \\
0.50 \\
0.18\end{array}$ \\
\hline
\end{tabular}

As the temperature increases, the damage reaction to the product is also faster so that the shelf life obtained is shorter (Table 5). At $4^{\circ} \mathrm{C}$ the storage temperature has the longest shelf life so the coffee beverage products to get a long shelf life, should be stored at a low temperature $\left(4^{\circ} \mathrm{C}\right)$.

From the calculation of the value of $\mathrm{k}$ (reaction rate) and activation energy at each temperature seen in Table 5, in line with the theory that the lower the value of the activation energy, the reaction rate goes fast, with this shorter shelf life. But from the results obtained, the total sugar should have a longer shelf life compared to other parameters, due to the slow rate of decline.

According to Anagari et al. (2011), in determining shelf life can not only be done by one method, sensory, physical or chemical or one particular method. This is due to each product has different characteristics when it is indifferent storage conditions (temperature). As additional data, the prediction of shelf life at $4^{\circ} \mathrm{C}$ is also carried out with a sensory test. The lowest prediction (lower) is taken it has a shelf life of 3.88 days. This beverage product is recommended to be stored at $4^{\circ} \mathrm{C}$. Therefore, the shelf life of this product is taken to predict the lowest shelf life for $4^{\circ} \mathrm{C}$ temperature is 4 days.

\section{CONCLUSIONS}

The results showed that during storage of mixed Arabica coffee drinks, a $\mathrm{pH}$ value decreased from 5.56 to 5.42-3.67, indicating that the product was getting more acidic. The number of microbes increased, from $1.92 \mathrm{log}$ $\mathrm{CFU} / \mathrm{mL}$ to 4.64-6.37 $\log \mathrm{CFU} / \mathrm{mL}$. Each parameter has a different activation energy value. The higher the storage temperature was proven to the smaller the activation energy. On the measurement of total microbes, the activation energy of each treatment temperature $4^{\circ} \mathrm{C}, 27^{\circ} \mathrm{C}$ and $37^{\circ} \mathrm{C}$ was $0.1731,0.1476$ and 0.1382 , respectively. Therefore, it was concluded to obtain a good quality storage and storage life used at $4^{\circ} \mathrm{C}$ with a shelf life of four days.

\section{REFERENCES}

Abduh, M. (2018). Dari ITB untuk Indonesia: Biorefinery Kopi. Institut Teknologi Bandung. Bandung.

Adi, K. (2013). Super Pintar Buku Kantong Kimia SMA Kelas X, XI, dan XII. Penerbit Cabe Rawit. Yogyakarta. 
Anagari, H.; S.A. Mustaniroh \& Wignyanto (2011). Penentuan umur simpan minuman fungsional sari akar alangalang dengan metode Accelerated Shelf Life Testing (ASLT) (Studi Kasus di UKM "R.Rovit" Batu-Malang). AGROINTEK, 5, 118-125.

Arif, A.B. (2016). Metode Accelarated Shelf Life Test (ASLT) dengan pendekatan arrhenius dalam pendugaan umur simpan sari buah nanas, pepaya dan cimpedak. Informatika Pertanian, 25, 189-198.

Arpah, M. (2001). Buku dan Monograf Penentuan Kadaluwarsa Produk Pangan. Program Pasca Sarjana IPB. Bogor.

Asiah, N.; L. Cempaka \& W. David. (2018). Panduan Praktis Pendugaan Umur Simpan Produk Pangan. Universitas Bakrie. Jakarta.

BPS (2017). Statistik Kopi Indonesia. Badan Pusat Statistik. Jakarta, Indonesia.

Culver, C.A. (2008). Color Quality of Fresh and Processed Foods. Chemical Society. Washington DC, USA.

Fuller, M. \& N. Rao (2017). The Effect of Time, Roasting Temperature, and Grind Size on Cafeine and Chlorogenic Acid Concentrations in Cold Brew Coffee. Scientific Report. Department of Chemistry and Biochemistry. Thomas Jefferson University, East Falls Campus. Philadelphia.

Guo, M.; J. Wu; Y. Xu; G. Xiao; M. Zhang \& Y. Chen (2011). Effects on microbial inactivation and quality attributes in frozenlychee juice treated by supercritical carbon dioxide. European Food Research Technology, 232, 803-811.

Hariyadi, P. (2019). Masa Simpan dan Batas Kadaluwarsa Produk Pangan: Pendugaan, Pengelolaan dan Penandaannya. PT. Gramedia Pustaka Utama. Jakarta.

Heeger, A.; A.K. Cagnazzo; C. Ennio; A. Wilfried (2016). Bioactives of coffee cherry pulp and its utilisation for production of Cascara beverage. Science Research, $3,120-127$.

Jaiswal, R.; M.A. Patras, P.J. Eravuchira \& N. Kuhnert (2010). Profile and characterization of the chlorogenic acids in green Robusta coffee beans by LC-MSn: Identification of seven new classes of compounds. Journal of Agriculture Food Chemistry, 58, 8722-8737.

Kemenperin (2017). Peluang Usaha IKM Kopi. Direktorat Jendral Industri Kecil dan Menengah Kementerian Perindustrian. Jakarta.

Kipkori, R.; S. Muhoho; P. Muliro; B. Mugendi; M. Frohme \& O. Broedel (2015). Effects of coffee processing technologies on aroma profiles and sensory quality of Ruiru 11 and SL 28 Kenyan coffee varieties. Asian Journal of Agriculture and Food Sciences, 03, 178-188.

Kurniawan, A. \& M.R. Rosyid. (2017). Perilaku konsumtif remaja penikmat warung kopi. Jurnal Sosiologi DILEMA, 32, 1 , 9-22.

Makfoeld, D. (2008). Kamus Istilah Pangan dan Nutrisi. Penerbit Kanisius. Yogyakarta

Muchtadi, T.R. \& Sugiyono (2013). Prinsip Proses dan Teknologi Pangan. Alfabet. Bandung.

Rahayu, W.P. \& C.C. Nurwitri (2012). Mikrobiologi Pangan. IPB Press. Bogor.

Sudewa, B. \& F. Hadiatna (2017). Evaluasi sensor FIT0348 sebagai alat ukur potential of hydrogen $(\mathrm{pH})$ larutan. Jurnal Elektro Telekomunikasi Terapan, 570-578.

Sudibyo, A.; T.F. Hutajulu \& Setyadjit (2010). Pendugaan masa simpan produk kopi instan menggunakan studi penyimpanan yang diakselerasi dengan model kinetika Arhenius. Journal of AgroBased Industry, 27, 12-14.

Swadana, A.W. \& S.S. Yuwono (2014). Pendugaan umur simpan minuman berperisa apel menggunakan metode Accelerated Shelf Life Testing (ASLT) dengan 
pendekatan Arrhenius. Jurnal Pangan dan Agroindustri, 2, 203-213.

Syah, D. (2012). Pengantar Teknologi Pangan. Penerbit IPB Press. Bogor.

Umanzor, C. (2017). Sensory Characterization and Analysis of Tea Infusions From Dry Coffee Cherry Pulp "Cascara" From Washed And Natural Processed Coffee". Master thesis. Coffee Economics and Science Ernesto Illy, Via Flavia, Trieste.

Xu, Z.; L. Zhanga; Y. Wanga; X. Bi; R. Buckow \& X. Liao (2011). Effects of high pressure $\mathrm{CO}_{2}$ treatments on microflora, enzymes and somequality attributes of apple juice. Journal Food English, 104, 577-584.
Yadav, R.; A. Tripathi \& A. Jha (2013). Effect of storage time on the physicochemical properties and sensory attributes of Aloe vera ready to serve (RTS) beverage. International Journal of Food, Nutrition and Pubic Health, 6, 173-192.

Yun, J.H.; Y.J. Cha \& D.S. Lee (2007). Storage stability and shelf life characteristics of korean savory sauce products. Journal Food Science and Nutrition, 12, 242-250. $* * 0 * *$ 